\title{
Impact of Capital Structure Decision on Firm Performance and Stock Return Pre during and Post Crisis: An Evidence from Developed and Developing Country
}

\author{
Sultan Mehmood* Muhammad Shaoor Ul Hassan Naqvi Muhammad Irfan \\ Riphah International University Islamabad, Pakistan
}

\begin{abstract}
The aim of this investigation is to determine how the financial crisis in 2008 influenced Capital Structure (CS) and firm performance relationship in developed (United State of America) and developing (Pakistan) countries, further how the company's CS affects stock return and EPS. The study sample consists of 130 firms listed on Pakistan Stock Exchange and 26 leading USA non-financial firms listed on New York Stock exchange (NYSE). To find answers to the questions of this investigation this research employed generalized method of moments (GMM) regression analysis. We split our sample period into two phases i.e. pre-crises (2004-2008) and post-crises (20092013). The sample of this study comprise of top US nonfinancial firms listed on the NYSE and Pakistani firms listed on a Pakistan stock exchange. The results indicate that CS has significant association with firm performance and earnings per share. However, the CS relationship with stock return is not significant in Pakistan after the crises. Specifically, an increase of one unit in debts to equity ratio lead to an increase of 0.42 in ROA before crises and the result is highly significant at level $1 \%$, however after crises the increase is 0.026 but insignificant. In addition, the relation of ROA with earning per share and stock return is also highly significant and positively post crises. On the other side, the relationship of EPS and stock return is positive but not significant after crises. Moreover, SR and EPS are related negatively with each other however the result is insignificant before crises, while after crises the result is positive and significant. For US firms, an increase of one unit in debts to equity ratio is linked with a rise of 0.019 in ROA before crises, and .0087 after crises. The results show significant level of $5 \%$ in both period of time in USA. If firms increase one percentage point of their leverage, their EPS and SR will increase 0.23 and 0.22 respectively before crisis. Whereas, after crisis EPS and SR increase is .008 and .009 with positive significant level 10\% and 5\% respectively. Furthermore, the relationship between CS and EPS as well as SR is also positive and significant pre-crises however post crises in case of SR the result is insignificant. The increase in EPS and SR is 0.42 and 0.41 before crises, and after crises the increase is 0.04 and 0.001 respectively. After crises EPS is significant at the 5\% level; however SR have insignificant relation after crises in Pakistan. Moreover, EPS is positively and insignificantly related with ROA and SR before crises, but the results after crises is highly significant and positive. A one unit change in SR will increase the value of ROA by 0.096 before crises. Whereas, after crisis the value of ROA rises by 0.113 . Results more over shows that EPS value increases by $10 \%$ if SR changes by one percent before crisis period. Whereas, after crises the increase is $8 \%$.
\end{abstract}

Keywords: Capital Structure, Financial Crisis, Firm's Performance, Debt to Equity Ratio

DOI: $10.7176 / \mathrm{RJFA} / 12-2-06$

Publication date: January $31^{\text {st }} 2021$

\subsection{Preamble}

Capital Structure (CS) decision and firm performance relation have been the focus of investigation for more than fifty years. This relationship involves the courtesy of several investigators such as Salim and Yadav (2012), Mujahid and Akhtar (2014), Demirhan and Anwar (2014) and in recent times Basit and Hassan (2017). In CS decisions a manager wants the firm value to be maximized by setting an optimal CS. An optimal CS would increase firms' value and its performance however the wrong decision may lead the firm to bankruptcy and financial distress.

Modigliani and Miller (1958) well-known Nobel Prize winner and financial economists conducted a study for the very first time in the history of CS. Their work known as MM theory assumes certain assumptions. MM theory highlighted that there is no optimum CS that will decrease WACC and maximize firm's value. Since then, many theories have been established, including Trade-off Theory (TOT), the Agency Cost Theory and Pecking Order Theory (POT). Pakistani companies' decisions are consistent with POT of CS (Ahmad, Fida, \& Zakaria, 2013).

Many researchers have identified various factors in the context of CS such as firm size, profitability, age, growth opportunity, liquidity, dividend policy, non-debt tax shields, tangibility and risk; that play a key role in enhancing firm value. Furthermore, Tongkong et al. (2012) described that profitability; firm size, growth and firms leverage are significant determinants of CS in the real estate industry in Thailand. Moosa and Li (2012) stated that liquidity is a major factor that negatively influences leverage. Charalambakis and Psychoyios (2012) argued that growth opportunities, tangibility, firm's size, and profitability affect firm's leverage. These four well-known firms- 
specific factors are the main determinants affecting the CS of the US and the UK firms. Recently Frank and Goyal (2009) on their evidence from publicly traded American firms; concluded that firm leverage, log of assets, inflation and profitability are the major determining factors.

Nevertheless, in the context of stock return, CS and firm's performance investigators have mostly focused on numerous factors such as profitability, firm size, growth, age, debt ratios, stock return, earning per shares and Liquidity. Ahmad et al. (2013) in their investigation on Pakistani textile firms; concludes that stock returns, debt to equity ratio, log of assets, return on equity ratio, earnings per share, time interest earned ratio and cash flow ratio are the main factors. According to Al Salamat and Mustafa (2016) stock return, size, liquidity, growth opportunities and profitability affect firm's debt ratio.

In addition, the global financial crises 2008 also make CS an important topic. This crisis started at the end of 2007 primarily in debt market and hit short-term money markets as well that led to a liquidity crisis (Fosberg, 2012). Numerous economists believe that the recent economic crisis was more fatal than the big depression of the 1930s (Business Wire News database, 2009). This is because many difficulties faced by companies were related to their CS decisions. Crotty (2009) described that corporations take debt to increase their capital in the period of financial crises, however higher debt level increases risk. As a result financial investigators have critically evaluated CS theories (Grove \& el., 2011). Thus, the financial crisis is a good period for studying CS decision and corporate performance as well as stock return in pre and after crisis period in different financial aspects.

Afterwards, some empirical studies on CS and firm performance in crises have been conducted in financial and non-financial firm's aspect. In Pakistan context, as per the investigator's knowledge, few researchers have investigated CS-performance relation pre and post-crises as compared to other countries like developed country USA. Recently, San and Heng (2011) describes the connection of firm's performance and CS in crisis period 2007 in construction industry firms listed on Bursa Malaysia. Erkens, Hung and Matos (2012) determine that selfgoverning board members raises more equity finance thus funds transfer toward the debt holder from shareholders. The study also documented that firms with institutional ownership in crisis era lead to face additional losses than other businesses. Ahmad, Fida and Zakaria (2013) examined the relationship between CS and stock return for the period 2006-2010. They also confirmed that debt and firm performance have positive link. Taiwo, Muyideen, and Tunde (2015) focused on the effect of CS on firm's performance in United State of America (USA) in the financial recession period 2008. Similarly, Khodavandloo, Zakaria and Nassir (2017) studied the linkage between CS and firm's performance in the period before and post crisis of 2008 .

\subsection{Statement of Problem}

Present days, corporations tend to use altering sources i.e. equity or debt to perform their operations when they want to expand their size or to increase returns. However, the circumstances are complex in actual competition and further become more complex in the crisis phase to survive in the industry, only few studies empirically investigated this relationship during financial crisis (Khodavandloo, Zakaria \& Nassir (2017). Recent financial crisis starts in the USA and affects a number of countries across the world. Many countries face financial instability and bears heavy losses; moreover the financial crises collapses the financial growth globally as well as performance (Taiwo, Muyideen, \& Tunde, 2015).

Pakistan has also faced this disaster in 2008 and faces sharp downfall in growth, firm liquidity, firm performance and rise in inflation. After many years of MM theories; investigators are still not agree on the boundary of the CS impact on firm performance around the world. In reality CS will lead to the success of firms and will also improve performance. Pakistan has already faced economic insecurity before the Global Financial Crisis 2008 that increases the financial problems in the country. In the period of crisis 2008; collapse in GDP growth rate, real GDP growth rate was significant and reach 1.6\%. However, upsurge in budget and current account shortfalls and rising inflation carried extra difficulties for Pakistan's economy.

As mentioned above, the problem can be expressed as the following: What is the impact of the CS decision on the firm's performance, stock return and Earning Per Share (EPS) in pre and post crisis period?

\subsection{Objectives of the Study}

This investigation aims to achieve the following objectives:

- First, the objective of this investigation is to observe the impact of CS decision on firm performance in Pakistan and USA before (2004-08) and after crisis period (2009-13);

- Second, to explore the effect of CS decision on stock return in Pakistan and USA before (2004-08) and after crisis period (2009-13);

- Third, to examine the effect of CS decision on EPS in Pakistan and USA before (2004-08) and after crisis period (2009-13);

\subsection{Research Questions}

1. Does CS decision influence firm performance? 
2. Does CS decision affect earnings per share?

3. What is the effect of CS decision on Stock return?

\subsection{Significance of the Study}

This study makes a contribution both to theory concerning CS and financial performance and also gives practical awareness for Pakistanis companies concerning how to manage the firm's CS for attaining healthier financial performance comparing with USA firms. This study will guide managers that what they do with the CS that will not adversely affect their performance in crises period.

\section{Empirical Literature}

Hossain and Nguyen (2016) discover the financial crisis and companies' performance evidence of Canadian firms. A sample of 10 large oil and gas firms listed on Canadian Stock Exchange over the period (2004-2013) are used for examining the above association. They split sample period into three stages pre-crisis (2004-2006), crisis (2007-2009), and post-crisis (2010-2013). They used method of univariate analysis and regression model for analyses. Their findings indicate that there is strong inverse relationship in all three periods.

Khodavandloo, Zakaria and Nassir (2017) examined the association between CS and firm's performance before, during and post crisis 2008. They applied simple and cross-sectional regression on a sample of 45 listed Bursa Malaysian companies of service and trading sector over the three specific periods pre (2004-2006), during (2007-2009) and recovery phase (2010-2013). They found that financial leverage negatively effect firm performance while more significant and stronger inverse relation was found during the crisis period.

Erkens, Hung and Matos (2012) examined the impact of firm governance on firms' financial performance during the period of crisis 2007-2008. For this purpose they use a parametric measure of 296 companies from thirty countries that were more affected by the crisis. They discover that independent board members increase more equity capital therefore capital transfer toward the debt holder from owners. Their study also reveals that firms with institutional ownership during the financial crisis face more losses than other companies.

Ahmad, Fida and Zakaria (2013) examined the link between CS and stock return by using a generalized method of moments (GMM) model. For this purpose investigators used 100 nonfinancial firms' data for the period of 2006-2010. They confirmed that debts ratio is favorably related to firm performance. Their study results also suggest that profitability is related positively to stock return.

Taiwo, Muyideen, and Tunde (2015) used data for the period before crisis phase 2003-2006, crises phase 2007-08 and after crises phase 2009-2012 by using multiple regression technique to examine CS-performance link in United State of America. The results showed mixed conclusions of CS and firm performance as study indicates that they are significantly negatively related in pre and after crises period, positive relation was found in post crises period between debt to equity and ROA. However, CS decision is not an important factor of firm performance in USA, thus study suggest that more focus is needed to enhance performance of companies than debt and equity selection.

San and Heng (2011) used data for the period 2005 to 2008 and employed pool regression technique. The purpose of their investigation was to find out the link between firms performance and CS. Investigators used more than 160 observations for 49 construction companies for the period of pre and post crises. They further divided firms in to main three groups small, medium and large. Their results showed that high debt equity ensures positive effect on company performance of large companies. They showed that earnings per share for small construction companies ensure significant connection with CS. Daskalakis and Psillaki (2008) predict firm's factors that determine CS in France and Greece in the period of 1997 to 2002. According to their results large firms use higher debt. Their finding related to assets structure and profitability is in line with TOT indicating inverse relationship with CS. Further, they find that firm size as well as growth is positively associated with debt.

The relation between CS and firm's profitability is still important topic for investigation; several theories have been explaining this association between CS and performance of the firm. Ahmad, Ahmed and Shabbir (2015) study the effect of financial decisions on the profitability of 111 textile firms'. They collect data from State Bank of Pakistan within for the period of 2006 to 2011. The results of the study displays that there is a significant direct link between assets turnover ratio, size and profitability however profitability is inversely related to growth, short term leverage, long term leverage and liquidity. Furthermore, the investigator's advice that firms should reduce the leverage level for the purpose of growth in profitability.

Similarly a study conducted by Salim and Yadav (2012) observes the effect of finance decisions on the performance of 237 Malaysian Listed Companies for a period from 1995-2011. They used ROA, ROE, Tobin's Q and EPS as dependent variables whereas long term debts (LTD), short term debts (STD), total debts (TD), size and growth as independent variables. The findings of the study show that growth in all sectors positively affect firm performance. Although, firm's performance was negatively related to STD, TD and LTD but STD and LTD positively influence Tobin's Q. Mujahid and Akhtar (2014) conducted an investigation to examine the link between CS and firm performance in Pakistan from 2006-2011. Their study sample comprise of 11 firms. They used i.e. 
ROE, ROA, and EPS as performance variables. Outcomes of the study display that CS positively influence shareholders worth as well as performance.

Using multiple regression model, Rouf (2015) tested the corporation's performance and CS relation for 106

Dhaka stock exchange listed non-financial firms. He uses return on sale and ROA as performance variables on the other hand debts to equity ratio, debts ratio, and current assets proprietors' funds ratio were used as CS measures. He suggests that debt equity ratio would negatively affect firm's performance. Similarly, Abeywardhana (2016) studied the effect of CS on performance of the firm for the period of 1998-2008 for United Kingdom SMEs. His results showed that CS and firm performance have negative correlation. Size as a control variable and corporate performance has positive correlation. However, study further reveals that firm will be successful if it uses internal resources than debt financing.

Using OLS, Kausar, Mian and Hashim (2014) examined the association between CS and companies performance in Pakistan from 2004-2011. Their study sample comprise of 197 non-financial firms. The study analyzes the relationship between CS proxies' i.e. total short term debts, total debt and total long term debts and performance proxies i.e. P/E and Tobin's Q. The growth, firm size, age and liquidity were used as a control variable. They found that CS significantly negatively affects companies' performance. Firm size and age have negative correlation with firm performance. The study also suggests that Pakistani firm rely on equity finance and large size firms are more ineffective with performance.

Demirhan and Anwar (2014) conducted a study to examine the effect of CS on firm financial performance in the context of an emerging market - Turkey during crisis 2008. The findings show that most of the Turkish companies were short of liquidity finance during the situations to run their operations. The results further reveal that high leverage negatively affects firm performance. Basit and Hassan (2017) used five performance measures, namely ROE, ROA, EPS, firm size, and marketing. They suggest no significant link between leverage and firm profitability ratios. Furthermore, they found that higher leverage decreases firm size.

Cole, Yan and Hemley (2015) explore the impact of CS on firm performance in the context of USA for three sectors Industrial, Healthcare, and Energy by taking 300 observations over the period (2004-2013). They used simple regressions models for analysis. In their study operating return, profit margin, ROA and market value per share were used as firm performance indicators, whereas CS is measured by long term liabilities ratio. They find that profit margin and CS have insignificant link in healthcare sector, negative association in energy sector, while positive in industrial sector. Companies perform differently in different sectors in terms of return against investments. Furthermore, firm performance and CS in their study were inversely related because debts are cheaper than equity by taking tax shield advantage for investments in all three sectors. Stock return is another dependent variable, which can be made in the shape of dividends. Al Salamat and Mustafa (2016) studied the influence of CS on performance of corporations by taking all industrial firms in Jordan over the period (2007-2014). They use T-test and F-test to examine the statistical relationship and significance by using a regression model for analysis. They found that CS and stock return have negative correlation. However, there is a positive correlation between stock return and liquidity of firms and ROA. In addition, EPS insignificantly affect stock return.

Ahmad et al. (2013) examines the impact of CS on stock return of 69 companies in textile sector in Pakistan for the period (2003-2009). The results showed a positive impact of debt to equity ratio on stock return and firm's earning per share (EPS). In addition, fall of Pakistani currency against US dollar effected Pakistan textile and the value of cotton falls internationally further innovation become more expensive. Tahmoorespour et al. (2015) explore the impact of CS on stock returns of 1082 firms of Asia Pacific countries over the 22 years period (19902012). They use method of regression and panel data for analyses. The results showed that stock return and leverage affect each other negatively in Australia, China, Singapore and South Korea. However, liability to capital and long term liability to capital directly and inversely affect stock return in Hong Kong. Study further reveals that capital decision and stock return depends on markets to markets and business nature.

\subsection{Hypothesis \\ $\mathrm{H}_{1}$ : CS and firm performance have significant relationship; \\ $\mathrm{H}_{2}$ : CS and EPS have significant relationship; \\ $\mathrm{H}_{3}$ : CS and stock return have significant relationship.}

\section{Research Methodology}

3.1 Sample of the Study

The population for this investigation is total non-financial firms listed on Pakistan and New York Stock Exchange. The study sample consists of 130 Pakistani and 26 leading USA non-financial firms from 2004-2013.

\subsection{Model Specification}

The current study explore the relation between CS, firm performance, stock return and EPS. The software used for estimation of parameters is STATA 12. For tackling endogeneity the study used GMM regression because 
endogeneity is a problem which makes the parameters biased and inconsistent (Roberts \& Whited, 2011). The dependent variable is used as lag variable on the right hand side so the model becomes dynamic whereas the independent variables lag values are used as instruments. The following GMM regression model is used:

$Y_{i t}=\beta_{0}+\beta_{1} Y_{i t-1}+\beta_{2} X_{i t}+\beta_{3} X_{i t}+\beta_{4} X_{i t}+\beta_{5} X_{i t}+\varepsilon_{i t}$

$R O A_{i t}=\beta_{0}+\beta_{1} Y_{i t-1}+\beta_{2} X_{i t}+\beta_{3} X_{i t}+\beta_{4} X_{i t}+\beta_{5} X_{i t}+\varepsilon_{i t}$

$E P S_{i t}=\beta_{0}+\beta_{1} Y_{i t-1}+\beta_{2} X_{i t}+\beta_{3} X_{i t}+\beta_{4} X_{i t}+\beta_{5} X_{i t}+\varepsilon_{i t}$

$S R_{i t}=\beta_{0}+\beta_{1} Y_{i t-1}+\beta_{2} X_{i t}+\beta_{3} X_{i t}+\beta_{4} X_{i t}+\beta_{5} X_{i t}+\varepsilon_{i t}$

Where:

ROA: Return on Assets;

EPS: Earning Per Shares;

SR: Stock Return;

$Y_{\mathrm{i}}=$ Dependent variable (ROA, Stock Return \& EPS);

$Y_{i t-1}=$ Lag value of dependent variable;

$X_{1 t}=$ Debt ratio;

$X_{2 t}=$ Growth;

$X_{3 t}=$ Age of firm;

$X_{4 t}=$ Size of the firm;

$\varepsilon_{i t}=$ The error term.

3.3 Variables Description

Table 1. Measurement of Variables

\begin{tabular}{|l|l|l|}
\hline Variable & Label & Description \\
\hline Dependent Variables & EPS & Net Income / Number of Shares Outstanding \\
\hline Earning Per Shares & ROA & Net Income / Total Assets \\
\hline Return on Assets & SR & $\begin{array}{l}\text { Today share price - previous share price / } \\
\text { previous share price }\end{array}$ \\
\hline Stock Return & \multicolumn{2}{|l|}{} \\
\hline Independent Variables & DTR & Total debt/shareholder equity \\
\hline Debt to Equity Ratio & GRO & The percentage change in total assets \\
\hline Growth & AGE & Firm listing history \\
\hline Firm Age & SZ & Natural log of total assets \\
\hline Firm's size &
\end{tabular}

\section{Empirical Results and Analysis}

In this section results are presented and analyzed. The first portion presents descriptive statistics for Pakistan and USA firms' pre and after crisis period. Thereafter, the correlation results are presented. Finally, regression results are provided.

\subsection{Descriptive Statistics}

Descriptive statistics have been widely used (Daskalakis \& Psillaki 2008; Umar et al., 2012; Khodavandloo, Zakaria \& Nassir, 2017), it measures mean, standard deviation, minimum and maximum values etc. Table 2 and 3 shows the descriptive statistics of Pakistan pre and post crises period respectively whereas 4 and 5 presents the descriptive statistics of USA pre and post crises respectively. The mean Return on Assets (ROA) is 0.066 for Pakistani firms before crisis however after crisis the mean value declines to 0.052 . This suggests that before crisis, firms have better return on assets and diminished by 0.014 after the crisis period in Pakistan. Furthermore, the value of standard deviation is higher post crisis (0.13) as compare to pre-crisis period (0.09), indicating higher variation in ROA after crisis. In addition, the highest total ROA achieved by firms before crisis is $71 \%$ and the lowest score is $-25 \%$, whereas for firms after crises the max and min ROA are $78 \%$ and $-121 \%$ respectively.

On the other hand, the mean ROA is 0.093 for US firms before crisis and 0.085 post crises, suggesting better return on assets in pre crises period. Thus, the mean ROA declines by 0.008 . Moreover, the standard deviation of ROA is 0.082 pre-crises and 0.051 post crises. The high total ROA achieved by US firms before crisis is $27 \%$ and the lowest is $-48 \%$, whereas after crises the max and min ROA are $34 \%$ and $-11 \%$ respectively. The study uses earnings per share to measure shareholder return. The result shows a decrease in EPS value for Pakistani firms after the crises. The value of EPS is lower after crises with a mean of 12.36. However, the mean EPS before crises is 13.51. Thus, earnings per shares mean value suggest that on average EPS value after the crises declines by 1.15 . Further, the findings suggest that pre crises, firms have min and max values of -31.84 and 300.88 respectively. 
Whereas, the min value of EPS is -130.62 and the max value is 460 post crises. For US firms, a lower mean EPS value shows a decline in EPS value after the crises. The value of EPS is lower in US firms after crises with a mean of 2.88 in USA as compare to 3.76 pre-crises. Thus, earnings per share mean value indicates that, on average, the EPS value of US firms after the crises is lower, then the value of the firms before the crisis period with a decrease of 0.88 . The results further indicate that pre crises, firms have min and max values of -14.86 and 9.72 respectively. However, the min value of EPS post crises is -6.41 and the max value is 14.94 . The stock returns (SR) mean value also declines after financial disaster. The mean value of the SR is 1.19 and -0.068 pre and post crises respectively. Thus, indicating a decline of 1.258 . Nevertheless, the mean SR of US firms are $12.07 \%$ and $10.99 \%$ pre and post crises respectively. Thus, similar to Pakistani firms US firms SR value declines after the crises period.

For Pakistani firms, Debt ratio (leverage) slightly increased after financial crisis. Before crisis, the mean debt ratio is $60 \%$, while the number increased to $63 \%$ after crisis. Hence, indicating an increase of almost $3 \%$. For US firms, before crisis, the mean debt ratio is 1.26 , whereas after crises the mean value increased to 2.20 . Thus, shows an increase of nearly 0.93 after the crisis. The results further shows that before crisis Pakistani firms have the highest mean growth which is $34.58 \%$, which declines to $17.68 \%$ post crises. It is also observed that growth ranges from -0.77 to 46.31 pre-crises, and -0.98 to 9.23 after crises. For US firms, before crisis the highest mean growth is 2.44 , which falls to 0.091 post crises. Thus, the descriptive static result shows that growth of US firms is heavily affected in USA by the financial crises. It is also observed that growth ranges from -0.98 to 297.2 before crises, and -0.99 to 1.37 after crises. For Pakistani firms, the mean value of firm size before crises is 8.12 . The min value of firm size before crises is 2.17 and the max value is 11.84 . However, the mean size is 8.72 after crises. Hence, the result shows that companies after crisis become larger in size, but the difference between them is small 0.6 on average. For US firms, before crises the mean value of firm size is 10.47 . Whereas, the min value before crises is 8.18 and the max value is 16.67 . However, the mean size is 10.83 after crises. Hence, the results display that firm after crisis becomes larger in size by a small margin of 0.36 . Furthermore, it can be seen that before crisis, firms have a mean age of 30.00 whereas after crises 29.70. On the hand, the mean firm age of US firms pre and post crises is 98.78 .

Table 2. Descriptive Statistics of Pakistani Firms Pre-Crises

\begin{tabular}{llllll}
\cline { 3 - 5 } Variables & Obs & Mean & Std. Dev & Min & Max \\
\hline ROA & 584 & 0.06674 & 0.09651 & -0.25 & 0.705 \\
EPS & 582 & 13.5134 & 28.3323 & -31.84 & 300.88 \\
SR & 454 & 1.19064 & 0.41950 & -0.75 & 2.07 \\
DTR & 584 & 0.60949 & 0.41224 & 0.08 & 4.15 \\
GRO & 496 & 0.34583 & 2.13238 & -0.77 & 46.31 \\
SZ & 582 & 8.12264 & 1.40534 & 2.17 & 11.84 \\
AGE & 584 & 30.0051 & 11.2522 & 10 & 56 \\
\hline
\end{tabular}

Table 3. Descriptive Statistics of Pakistani Firms Post-Crises

\begin{tabular}{llllll}
\cline { 4 - 5 } Variables & Obs & Mean & Std. Dev & Min & Max \\
\hline ROA & 654 & 0.05251 & 0.12994 & -1.2071 & .7836 \\
EPS & 651 & 12.3626 & 42.8334 & -130.62 & 460 \\
SR & 653 & -0.0686 & 11.8134 & -1 & 287.41 \\
DTR & 654 & 0.63373 & 0.55566 & .0235 & 9.8067 \\
GRO & $\mathbf{6 5 4}$ & 0.17683 & 0.51432 & -.9835 & 9.2331 \\
SZ & 654 & 8.72301 & 0.51432 & 3.0272 & 12.426 \\
AGE & 654 & 29.7033 & 11.1708 & 10 & 56 \\
\hline
\end{tabular}

Table 4. Descriptive Statistics of US Firms Pre-Crises

\begin{tabular}{llllll} 
& & & & & \\
\cline { 4 - 5 } Variable & Obs & Mean & Std. Dev & Min & Max \\
\hline ROA & 130 & 0.09363 & 0.08261 & -0.48563 & 0.2778 \\
EPS & 130 & 3.76444 & 2.67892 & -14.86 & 9.72 \\
SR & 104 & 0.12078 & 0.22913 & -0.49443 & 0.9944 \\
DTR & 130 & 1.26824 & 4.67532 & -48.092 & 12.338 \\
GRO & 129 & 2.44590 & 26.1753 & -0.9853 & 297.261 \\
SZ & 130 & 10.47494 & 1.51833 & 8.18909 & 16.6771
\end{tabular}




\begin{tabular}{lcclll}
\hline \multirow{2}{*}{ AGE } & 130 & 98.76923 & 41.2689 & 20 & 170 \\
\hline \multicolumn{7}{l}{ Table 5. Descriptive Statistics of US Firms Post-Crises } & & & \\
\hline \multicolumn{7}{l}{ Variables } & Obs & Mean & Std. Dev & Min & Max \\
\hline ROA & 130 & 0.08502 & 0.05104 & -0.1163 & 0.3422 \\
EPS & 130 & 2.88133 & 2.78559 & -6.41 & 14.94 \\
SR & 130 & 0.1099 & 0.26371 & -0.7939 & 1.8068 \\
DTR & 130 & 2.19943 & 3.82492 & 0.318 & 26.889 \\
GRO & 130 & 0.09186 & 0.22304 & -0.9989 & 1.3749 \\
SZ & 130 & 10.8304 & 1.25375 & 8.95704 & 17.215 \\
AGE & 130 & 98.7692 & 41.2689 & 20 & 170 \\
\hline
\end{tabular}

\subsection{Regression Analysis}

Regression is one of the commonly used statistical methods in investigation of data analysis. This study employs Generalized Method of Moments (GMM) to discover the statistical relation between CS, firm performance, EPS and stock return, pre as well as post crisis. The lag values of dependent variables of Pakistani firms are extremely significant at the level of $1 \%$ pre and post-crises. Hence, the results describe that the lag values of ROA, EPS and SR is $0.91,0.93$ and 0.89 before crises, and $0.86,0.85$, and 0.80 after crises respectively. Thus, the speed of adjustment toward the target ROA, EPS and SR are 9\%, 7\% and $11 \%$ before crises, while $14 \%, 15 \%$ and $20 \%$ respectively after crises. For US, the lag values of ROA, EPS and SR are $0.88,0.91$ and 0.89 respectively before crisis. Hence, the speed of adjustment towards target ROA, EPS and SR is $12 \%, 9 \%$ and $11 \%$ respectively. In addition, the lag values of these three dependent variables are $0.90,0.93$ and 0.94 and with a speed of adjustment values of $10 \%, 7 \%$, and $6 \%$ in the post crisis period respectively.

The GMM regression results related to CS and ROA as well as EPS in developing country (Pakistan) are similar to the results of US firms. The results indicate that CS has significant association with firm performance and earnings per share. However, the CS relationship with stock return is not significant in Pakistan after the crises. Specifically, an increase of one unit in debts to equity ratio lead to an increase of 0.42 in ROA before crises and the result is highly significant at level $1 \%$, however after crises the increase is 0.026 but insignificant. In addition, the relation of ROA with earning per share and stock return is also highly significant and positively post crises. On the other side, the relationship of EPS and stock return is positive but not significant after crises. Moreover, SR and EPS are related negatively with each other however the result is insignificant before crises, while after crises the result is positive and significant.

For US firms, an increase of one unit in debts to equity ratio is linked with a rise of 0.019 in ROA before crises, and .0087 after crises. The results show significant level of $5 \%$ in both period of time in USA. If firms increase one percentage point of their leverage, their EPS and SR will increase 0.23 and 0.22 respectively before crisis. Whereas, after crisis EPS and SR increase is .008 and .009 with positive significant level $10 \%$ and $5 \%$ respectively. These results are against the outcomes of (Tahmoorespour et al., 2015; Khodavandloo, Zakaria \& Nassir, 2017; Al Salamat \& Mustafa, 2016), who discovers significant negative linkage of debt ratio with ROA, EPS and SR. On the other hand, return on assets, earnings per share and stock return have positively link with leverage in the studies of (Ahmad et al., 2013; San \& Heng, 2011; Taiwo at al., 2015).

Furthermore, the relationship between CS and EPS as well as SR is also positive and significant pre-crises however post crises in case of SR the result is insignificant. The increase in EPS and SR is 0.42 and 0.41 before crises, and after crises the increase is 0.04 and 0.001 respectively. After crises EPS is significant at the 5\% level; however SR have insignificant relation after crises in Pakistan. Khodavandloo et al (2017) investigation shows that total debt to total equity is significantly effect on ROA. For US, study results reveal that the relation of ROA with EPS and SR is significant and positive in both periods of time in the USA. Al Salamat and Mustafa (2016) also found a positive relation between ROA and stock return but negative and insignificant relation with EPS. Moreover, EPS is positively and insignificantly related with ROA and SR before crises, but the results after crises is highly significant and positive. A one unit change in SR will increase the value of ROA by 0.096 before crises. Whereas, after crisis the value of ROA rises by 0.113 . Results more over shows that EPS value increases by $10 \%$ if SR changes by one percent before crisis period. Hence, after crises the increase is $8 \%$.

The relationship between age and ROA is positive and highly significant in Pakistan in both phases of crises. Further, the firm age relationship with EPS and SR is also positive and significant in both time periods. Furthermore, in case of US firm age is positive but insignificantly related with ROA both before and after the crisis. Firm's age relationship with EPS is insignificant before and after crises. Stock return is insignificant and inversely associated with firm age in both period times.

Growth relation with ROA is positive and significant at the level of 5\% before crises in Pakistan; moreover result shows that growth opportunity brings higher increases in ROA after crises and the result is significant at 
level $1 \%$. On the other side, growth relation with EPS and SR is also positive and significant. For US, ROA, EPS and SR are positively associated with growth and significant level is $1 \%$ before crises. But after crises, the relationship is negative but insignificant in all three regressions.

The variable firm size also positively affects ROA, EPS and SR and the result is significant. Specifically, one unit increase in firms' size is related to an increase of 0.052 in ROA before crises and the result is significant at level $5 \%$, where after crises the increase is 0.053 which is also significant. Furthermore, EPS and SR also increase with respect to firm size by 0.068 and 0.076 respectively, while after crises the increase is 0.030 and 0.026 respectively. In case of US, an increase of one unit in size increases ROA by 0.014 before crises and 0.010 after crises. When firm's size increases by one unit EPS and SR increases by 0.017 and 0.014 respectively before crisis. Whereas, after crisis EPS and SR increases by 0.007 and 0.005 respectively in USA. This finding is similar to the findings of Abeywardhana (2016) and Ahmad et al. (2015).

Table 6. Regression Results for Pakistan (Pre-Crises)

\begin{tabular}{|c|c|c|c|}
\hline Variables & ROA & EPS & SR \\
\hline \multirow[t]{2}{*}{$(-1)$} & $0.9179 * * *$ & $0.9384 * * *$ & $0.8937 * * *$ \\
\hline & $(0.000)$ & $(0.000)$ & $(0.000)$ \\
\hline \multirow[t]{2}{*}{ ROA } & & $0.0004 * * *$ & $0.0539 * * *$ \\
\hline & & $(0.005)$ & $(0.000)$ \\
\hline \multirow[t]{2}{*}{ EPS } & $0.3395 * * *$ & & $0.0036 * * *$ \\
\hline & $(0.000)$ & & $(0.000)$ \\
\hline \multirow[t]{2}{*}{ SR } & $0.2647 * * *$ & -0.0433 & \\
\hline & $(0.000)$ & $(0.356)$ & \\
\hline \multirow[t]{2}{*}{ Debt/Equity } & $0.4299 * * *$ & $0.4293 * * *$ & $0.4093 * * *$ \\
\hline & $(0.000)$ & $(0.000)$ & $(0.000)$ \\
\hline \multirow{2}{*}{ Firm Age } & $0.0229 * * *$ & $0.0231 * * *$ & $0.0221 * *$ \\
\hline & $(0.005)$ & $(0.001)$ & $(0.027)$ \\
\hline \multirow[t]{2}{*}{ Growth } & $0.0152 * *$ & $0.0211 * * *$ & $0.0233 * * *$ \\
\hline & $(0.026)$ & $(0.001)$ & $(0.001)$ \\
\hline \multirow[t]{2}{*}{ Size } & $0.0527 * *$ & $0.0688 * * *$ & $0.0760 * *$ \\
\hline & $(0.019)$ & $(0.000)$ & $(0.020)$ \\
\hline \multirow[t]{2}{*}{ Cons } & $-0.1299 * * *$ & $-0.278 * * *$ & $-0.107 * * *$ \\
\hline & $(0.000)$ & $(0.000)$ & $(0.000)$ \\
\hline \multirow[t]{2}{*}{ [AR-1] } & -2.01 & -2.01 & -2.04 \\
\hline & $(0.044)$ & $(0.045)$ & $(0.042)$ \\
\hline \multirow[t]{2}{*}{ [AR-2] } & 0.52 & 0.50 & 0.56 \\
\hline & $(0.603)$ & $(0.619)$ & $(0.577)$ \\
\hline F-Significance & $(0.000)$ & $(0.000)$ & $(0.000)$ \\
\hline Instruments & 158 & 158 & 158 \\
\hline \multirow[t]{2}{*}{ Hansen test } & 161.86 & 162.50 & 165.80 \\
\hline & $(0.206)$ & $(0.196)$ & $(0.151)$ \\
\hline \multirow[t]{2}{*}{ Difference in Hansen test } & 152.04 & 153.04 & 156.73 \\
\hline & $(0.248)$ & $(0.231)$ & $(0.173)$ \\
\hline
\end{tabular}

Note. $* * *, * *, *=$ statistical significance at the level of $1 \%, 5 \%$ and $10 \%$. 
Vol.12, No.2, 2021

Table 7. Regression Results for Pakistan (Post-Crises)

\begin{tabular}{|c|c|c|c|}
\hline Variables & ROA & EPS & SR \\
\hline$(-1)$ & $\begin{array}{l}0.8601 * * * \\
(0.000)\end{array}$ & $\begin{array}{l}0.8531 * * * \\
(0.000)\end{array}$ & $\begin{array}{l}0.8085^{* * *} \\
(0.000)\end{array}$ \\
\hline ROA & & $\begin{array}{l}0.4103 * * * \\
(0.000)\end{array}$ & $\begin{array}{l}0.1559 * * * \\
(0.000)\end{array}$ \\
\hline EPS & $\begin{array}{l}0.6478^{* * * *} \\
(0.000)\end{array}$ & & $\begin{array}{l}0.0109 \\
(0.374)\end{array}$ \\
\hline SR & $\begin{array}{l}0.8267 * * * \\
(0.000)\end{array}$ & $\begin{array}{l}0.0319 * * * \\
(0.000)\end{array}$ & \\
\hline Debt/Equity & $\begin{array}{l}0.0268 * \\
(0.061)\end{array}$ & $\begin{array}{l}0.0427 * * \\
(0.044)\end{array}$ & $\begin{array}{l}0.0019 \\
(0.883)\end{array}$ \\
\hline Firm Age & $\begin{array}{l}0.0149 * * * \\
(0.000)\end{array}$ & $\begin{array}{l}0.0174 * * * \\
(0.000)\end{array}$ & $\begin{array}{l}0.0147 * * * \\
(0.000)\end{array}$ \\
\hline Growth & $\begin{array}{l}0.0599 * * * \\
(0.000)\end{array}$ & $\begin{array}{l}0.0830 * * * \\
(0.000)\end{array}$ & $\begin{array}{l}0.0825 * * * \\
(0.000)\end{array}$ \\
\hline Size & $\begin{array}{l}0.0539 * * * \\
(0.000)\end{array}$ & $\begin{array}{l}0.0307 * * * \\
(0.000)\end{array}$ & $\begin{array}{l}0.0262 * * * \\
(0.000)\end{array}$ \\
\hline Cons & $\begin{array}{l}0.0635 * * \\
(0.011)\end{array}$ & $\begin{array}{l}-0.3858 * * * \\
(0.000)\end{array}$ & $\begin{array}{l}-0.0937^{*} \\
(0.059)\end{array}$ \\
\hline [AR-1] & $\begin{array}{l}-1.11 \\
(0.0266)\end{array}$ & $\begin{array}{l}-1.14 \\
(0.0256)\end{array}$ & $\begin{array}{l}-1.11 \\
(0.0266)\end{array}$ \\
\hline $\begin{array}{l}{[\mathrm{AR}-2]} \\
\text { F-Significance }\end{array}$ & $\begin{array}{l}0.97 \\
(0.332) \\
(0.000)\end{array}$ & $\begin{array}{l}0.97 \\
(0.333) \\
(0.000)\end{array}$ & $\begin{array}{l}0.98 \\
(0.329) \\
(0.000)\end{array}$ \\
\hline Instruments & 80 & 80 & 80 \\
\hline Hansen test & $\begin{array}{l}63.40 \\
(0.698)\end{array}$ & $\begin{array}{l}63.96 \\
(0.680)\end{array}$ & $\begin{array}{l}63.86 \\
(0.684)\end{array}$ \\
\hline Difference in Hansen test & $\begin{array}{l}58.50 \\
(0.603)\end{array}$ & $\begin{array}{l}57.13 \\
(0.651)\end{array}$ & $\begin{array}{l}61.53 \\
(0.493)\end{array}$ \\
\hline
\end{tabular}

Note. ${ }^{* * *}, * *, *=$ statistical significance at the level of $1 \%, 5 \%$ and $10 \%$. 
Table 8. Regression Results for US (Pre-Crises)

\begin{tabular}{|c|c|c|c|}
\hline Variables & ROA & EPS & SR \\
\hline$(-1)$ & $\begin{array}{l}0.8872 * * * \\
(0.000)\end{array}$ & $\begin{array}{l}0.9185^{* * *} \\
(0.000)\end{array}$ & $\begin{array}{l}0.8928 * * * \\
(0.000)\end{array}$ \\
\hline ROA & & $\begin{array}{l}0.0020 * * * \\
(0.000)\end{array}$ & $\begin{array}{l}0.0020 * * * \\
(0.000)\end{array}$ \\
\hline EPS & $\begin{array}{l}0.0000 \\
(0.856)\end{array}$ & & $\begin{array}{l}0.0001 \\
(0.748)\end{array}$ \\
\hline SR & $\begin{array}{l}0.0964 * * * \\
(0.000)\end{array}$ & $\begin{array}{l}0.1096^{* * *} \\
(0.000)\end{array}$ & \\
\hline Debt/Equity & $\begin{array}{l}0.0196 * * \\
(0.026)\end{array}$ & $\begin{array}{l}0.0239 * * * \\
(0.008)\end{array}$ & $\begin{array}{l}0.0227 * * * \\
(0.006)\end{array}$ \\
\hline Firm Age & $\begin{array}{l}0.0004 \\
(0.588)\end{array}$ & $\begin{array}{l}0.0003 \\
(0.653)\end{array}$ & $\begin{array}{l}-0.0003 \\
(0.652)\end{array}$ \\
\hline Growth & $\begin{array}{l}0.0391 * * * \\
(0.000)\end{array}$ & $\begin{array}{l}0.0446^{* * * *} \\
(0.000)\end{array}$ & $\begin{array}{l}0.0378 * * * \\
(0.000)\end{array}$ \\
\hline Size & $\begin{array}{l}0.0147 * * * \\
(0.000)\end{array}$ & $\begin{array}{l}0.01791 * * * \\
(0.000)\end{array}$ & $\begin{array}{l}0.0148 * * * \\
(0.000)\end{array}$ \\
\hline Cons & $\begin{array}{l}0.1347 * * * \\
(0.000)\end{array}$ & $\begin{array}{l}0.1532 * * * \\
(0.000)\end{array}$ & $\begin{array}{l}0.1322 * * * \\
(0.000)\end{array}$ \\
\hline [AR-1] & $\begin{array}{l}-4.24 \\
(0.000)\end{array}$ & $\begin{array}{l}-4.26 \\
(0.000)\end{array}$ & $\begin{array}{l}-4.24 \\
(0.000)\end{array}$ \\
\hline [AR-2] & $\begin{array}{l}0.66 \\
(0.507)\end{array}$ & $\begin{array}{l}0.95 \\
(0.340)\end{array}$ & $\begin{array}{l}0.80 \\
(0.422)\end{array}$ \\
\hline F-Significance & $(0.000)$ & $(0.000)$ & $(0.000)$ \\
\hline Instruments & 47 & 47 & 47 \\
\hline Hansen test & $\begin{array}{l}40.88 \\
(0.304)\end{array}$ & $\begin{array}{l}41.10 \\
(0.296)\end{array}$ & $\begin{array}{l}40.10 \\
(0.334)\end{array}$ \\
\hline Difference in Hansen test & $\begin{array}{l}37.62 \\
(0.228)\end{array}$ & $\begin{array}{l}38.41 \\
(0.202)\end{array}$ & $\begin{array}{l}38.14 \\
(0.210)\end{array}$ \\
\hline
\end{tabular}

Note. $* * *, * *, *=$ statistical significance at the level of $1 \%, 5 \%$ and $10 \%$. 
Table 9. Regression Results for US (Post-Crises)

\begin{tabular}{|c|c|c|c|}
\hline & ROA & EPS & SR \\
\hline$(-1)$ & $\begin{array}{l}0.9049 * * * \\
(0.000)\end{array}$ & $\begin{array}{l}0.9381 * * * \\
(0.000)\end{array}$ & $\begin{array}{l}0.9479 * * * \\
(0.000)\end{array}$ \\
\hline ROA & & $\begin{array}{l}0.0003 * * * \\
(0.000)\end{array}$ & $\begin{array}{l}0.0002^{* *} \\
(0.031)\end{array}$ \\
\hline EPS & $\begin{array}{l}0.0023 * * * \\
(0.000)\end{array}$ & & $\begin{array}{l}0.0017 * * * \\
(0.000)\end{array}$ \\
\hline SR & $\begin{array}{l}0.1131 * * * \\
(0.000)\end{array}$ & $\begin{array}{l}0.0892 * * * \\
(0.000)\end{array}$ & \\
\hline Debt/Equity & $\begin{array}{l}0.0087 * * \\
(0.049)\end{array}$ & $\begin{array}{l}0.0084^{*} \\
(0.057)\end{array}$ & $\begin{array}{c}0.0091 * * \\
(0.036)\end{array}$ \\
\hline Firm Age & $\begin{array}{l}0.0002 \\
(0.631)\end{array}$ & $\begin{array}{l}-0.0001 \\
(0.851)\end{array}$ & $\begin{array}{l}-0.0003 \\
(0.415)\end{array}$ \\
\hline Growth & $\begin{array}{l}-0.0069 \\
(0.112)\end{array}$ & $\begin{array}{r}-0.0048 \\
(0.265)\end{array}$ & $\begin{array}{r}-0.0034 \\
(0.434)\end{array}$ \\
\hline Size & $\begin{array}{l}0.0109^{* *} \\
(0.013)\end{array}$ & $\begin{array}{c}0.00770 * * \\
(0.038)\end{array}$ & $\begin{array}{l}0.0056^{*} \\
(0.075)\end{array}$ \\
\hline Cons & $\begin{array}{l}0.1638^{* * *} \\
(0.004)\end{array}$ & $\begin{array}{l}0.1090 * * \\
(0.031)\end{array}$ & $\begin{array}{l}0.0648 \\
(0.124) \\
\end{array}$ \\
\hline [AR-1] & $\begin{array}{l}-3.45 \\
(0.001)\end{array}$ & $\begin{array}{l}-3.41 \\
(0.001)\end{array}$ & $\begin{array}{l}-3.42 \\
(0.001)\end{array}$ \\
\hline [AR-2] & $\begin{array}{l}-0.77 \\
(0.440)\end{array}$ & $\begin{array}{l}-0.76 \\
(0.447)\end{array}$ & $\begin{array}{l}-0.75 \\
(0.454)\end{array}$ \\
\hline F-Significance & $(0.000)$ & $(0.000)$ & $(0.000)$ \\
\hline Instruments & 57 & 57 & 57 \\
\hline Hansen test & $\begin{array}{l}46.21 \\
(0.505)\end{array}$ & $\begin{array}{l}45.25 \\
(0.545)\end{array}$ & $\begin{array}{l}47.22 \\
(0.463)\end{array}$ \\
\hline Difference in Hansen test & $\begin{array}{l}39.76 \\
(0.266)\end{array}$ & $\begin{array}{l}38.74 \\
(0.305)\end{array}$ & $\begin{array}{l}40.11 \\
(0.254)\end{array}$ \\
\hline
\end{tabular}

Note. $* * *, * *, *=$ statistical significance at the level of $1 \%, 5 \%$ and $10 \%$.

\subsection{Conclusion}

The aim of this investigation is to determine how the financial crisis in 2008 influenced CS and firm performance relationship in developed (United State of America) and developing (Pakistan) countries, further how the company's CS affects stock return and EPS. The financial crisis 2008 affects a number of countries across the world. Many countries face financial instability and bears heavy losses; moreover the financial crises collapse the financial growth globally as well as performance (Taiwo, Muyideen, \& Tunde, 2015). Pakistan has also faced sharp downfall in growth, liquidity, performance and rise in inflation due to this crises. There are a number of studies that investigated the relationship between CS and firm performance in Pakistan. However, according to the author's knowledge, there is no study which examined the relationship between CS and firm performance by comparing developed and developing countries and before and after crisis.

The population for this investigation is total non-financial firms listed on Pakistan Stock Exchange and New York Stock Exchange. The study sample consists of 130 firms listed on Pakistan Stock Exchange and 26 leading USA non-financial firms listed on New York Stock exchange (NYSE) for the period 2004 to 2013. The software used for estimation of parameters is STATA 12. To find answers to the questions of this investigation this research employed generalized method of moments (GMM) regression analysis. We split our sample period into two phases i.e. pre-crises (2004-2008) and post-crises (2009-2013). The sample of this study comprise of top US nonfinancial firms listed on the NYSE and Pakistani firms listed on a Pakistan stock exchange.

The summary statistics shows that the mean Return on Assets (ROA) is 0.066 for Pakistani firms before crisis however after crisis the mean value declines to 0.052 . This suggests that before crisis, firms have better return on assets and diminished by 0.014 after the crisis period in Pakistan. On the other hand, the mean ROA is 0.093 for US firms before crisis and 0.085 post crises, suggesting better return on assets in pre crises period. Thus, the mean 
ROA declines by 0.008 . Moreover, the standard deviation of ROA is 0.082 pre-crises and 0.051 post crises.

The result shows a positive increase in EPS value for Pakistani firms after the crises. The value of EPS is higher after crises with a mean of 13.51. However, the mean EPS before crises is 12.36. Thus, earnings per shares mean value suggest that on average EPS value after the crises is high with an increase of 1.15. For US firms, a high mean EPS value shows an increase in EPS value after the crises. The value of EPS is higher in US firms after crises with a mean of 3.76 in USA as compare to 2.88 pre-crises. Thus, earnings per share mean value indicates that, on average, the EPS value of US firms after the crises is high, then the value of the firms before the crisis period with an increase of 0.88 .

The stock returns (SR) mean value gradually increases after financial disaster. The mean value of the SR is 0.068 and 1.19 pre and post crises respectively. Thus, showing an increase of 1.258. Nevertheless, the mean SR of US firms are $12.07 \%$ and $10.99 \%$ pre and post crises respectively. Thus, as compare to Pakistani firms, US firms SR value declines after the crises period.

For Pakistani firms, Debt ratio (leverage) slightly increased after financial crisis. Before crisis, the mean debt ratio is $60 \%$, while the number increased to $63 \%$ after crisis. Hence, indicating an increase of almost $3 \%$. For US firms, before crisis, the mean debt ratio is 1.26 , whereas after crises the mean value increased to 2.20 . Thus, shows an increase of nearly 0.93 after the crisis. In order to check multicollinearity in the data the study employed correlation matrix to examine correlations between explanatory variables. The results indicate that there is no such problem in the data as no correlation exceeds 0.80 .

The GMM regression results related to CS and ROA as well as EPS in developing country (Pakistan) are similar to the results of US firms. The results indicate that CS has significant association with firm performance and earnings per share. However, the CS relationship with stock return is not significant in Pakistan after the crises. Specifically, an increase of one unit in debts to equity ratio lead to an increase of 0.42 in ROA before crises and the result is highly significant at level $1 \%$, however after crises the increase is 0.026 but insignificant. In addition, the relation of ROA with earning per share and stock return is also highly significant and positively post crises. On the other side, the relationship of EPS and stock return is positive but not significant after crises. Moreover, SR and EPS are related negatively with each other however the result is insignificant before crises, while after crises the result is positive and significant.

For US firms, an increase of one unit in debts to equity ratio is linked with a rise of 0.019 in ROA before crises, and .0087 after crises. The results show significant level of $5 \%$ in both period of time in USA. If firms increase one percentage point of their leverage, their EPS and SR will increase 0.23 and 0.22 respectively before crisis. Whereas, after crisis EPS and SR increase is .008 and .009 with positive significant level $10 \%$ and $5 \%$ respectively.

Furthermore, the relationship between CS and EPS as well as SR is also positive and significant pre-crises however post crises in case of SR the result is insignificant. The increase in EPS and SR is 0.42 and 0.41 before crises, and after crises the increase is 0.04 and 0.001 respectively. After crises EPS is significant at the 5\% level; however SR have insignificant relation after crises in Pakistan. Moreover, EPS is positively and insignificantly related with ROA and SR before crises, but the results after crises is highly significant and positive. A one unit change in SR will increase the value of ROA by 0.096 before crises. Whereas, after crisis the value of ROA rises by 0.113 . Results more over shows that EPS value increases by $10 \%$ if SR changes by one percent before crisis period. Whereas, after crises the increase is $8 \%$.

\subsection{Future Recommendations}

As per the investigation results and conclusions presented in above sections, the investigator suggests the following recommendations for future:

- This research lacks the CS-performance relationship in the crises period, hence future research can split the time frame into three periods;

- Future research further needs to compare the 1997 and 2008 financial crises and investigate their impact on performance;

- In the future researchers needs to use different performance measure to see if the results are the same;

- Future research also needs to split the sample firms into small, medium and large to study CS-performance link in light of financial crises;

\section{References}

Abbasi, E., \& Delghandi, M. (2016). Impact of firm specific factors on capital; structure based on trade-off theory and pecking order theory: An Empirical study of the Tehran's Stock Market companies. Arabian Journal of Business and Management Review, Vol, 6, 1-4.

Abbas, Q., Hunjra, A. I., Azam, R. I., Ijaz, M. S., \& Zahid, M. (2014). Financial performance of banks in Pakistan after merger and acquisition. Journal of Global Entrepreneurship Research, Vol, 4(13), 1-15.

Abeywardhana, S. (2016). Impact of capital structure on firm performance: Evidence from manufacturing sector 
SMEs in UK. Electronic Journal.

Ahmad, H., Fida, S., \& Zakaria, K. (2013). The co-determinants of capital structure and stock returns: Evidence from the Karachi Stock Exchange. The Lahore Journal of Economics, Vol, 18(1), 81-92.

Ahmad, W., Ahmed, T., \& Shabbir, G. (2015). Determinants of textile firms' profitability in Pakistan. Forman Journal of Economic Studies, Vol, 11, 87-101.

Achilleas, K., Konstantina, P., \& Fotios, C. (2017). Economic crisis and firms' performance: Empirical evidence for the Greek cheese industry. Revista Galega De Economia, Vol, 26(1), 73-82.

Al-Tally, K. (2014). An Investigation of the Effect of Financial Leverage on Firm Financial Performance in Saudi Arabia's Public Listed Companies. Victoria University.

Altman, H. (1984). A further empirical investigation of the bankruptcy cost question. The Journal of Finance, Vol, $39,1067-1089$

Altman, E. I. (2002). Managing credit risk: A challenge for the new millennium. Economic Notes, Vol, 31(2), 201214.

Amidu, M. (2007). Determinants of capital structure of banks in Ghana. Baltic Journal of Management, Vol, 2(1), $67-79$.

Ariss, R. T. (2008). Financial liberalization and bank efficiency: Evidence. Applied Financial Economics, Vol, 18, 931-946.

Baker, M., \& Wurgler, J. (2002). Market timing and capital structure. The Journal of Finance, Vol, 57(1), 1-32.

Barr, R. S., Killgo, K. A., Siems, T. F., \& Zimmel, S. (2002). Evaluating the productive efficiency and performance of. Managerial Finance, Vol, 28(8) 3-25.

Basit, A., \& Hassan, Z. (2017). Impact of capital structure on firm's performance: A study on Karachi Stock Exchange (KSE) listed firms in Pakistan. International Journal of Management, Accounting and Economics, Vol, 4(2), 118-135.

Batool, A., Hashim, S., \& Tariq, H. (2017). Financial leverage and its impact on investment: A case study of PepsiCo, Inc. Gomal. Journal of Social Sciences and Humanities, Vol, 1(1), 23-34.

Baxter, N. D. (1967). Leverage, risk of ruin and the cost of capital. The Journal of Finance, 22(3), 395-403.

Bondt, D., \& Thompson, H. E. (1992). Is economic efficiency the driving force behind mergers? Managerial and Decision Economics, Vol, 13(1), 31-44.

Brigham, E., \& Ehrhardt, M. (2011). Mason: South-Western Cengage Learning. (1 Ed.) Financial Management: Theory and Practice.

Burger, A., Damijan, J., Kostevc, C., \& Rojec, M. (2013). Determination of firm performance and growth during economic recession: The case of central and eastern countries. Institute for economic research, Vol, paper no. 1.09

Cetorelli, N., \& Strahan, P. E. (2006). Finance as a barrier to entry: Bank competition and industry structure in local U.S. markets. The Journal of Finance, Vol, 61, 437-461.

Chakraborty, I. (2010). Capital structure in an emerging stock market: The case of India. Research in International Business and Finance, Vol, 24(3), 295-314.

Charalambakis, E. C., \& Psychoyios, D. (2012). What do we know about capital structure? Revisiting the impact of debt ratios on some firm-specific factors. Applied Financial Economics, Vol, 22(20), 1727-1742.

Chronopoulos, D. K., Girardone, C., \& Nankervis, J. C. (2011). Are there any cost and profit efficiency gains. European Journal of Finance, Vol, 17(8), 603-621.

Chunhua, W., \& Meiyan, S. (2013). Relationship between capital structure and performance evidence based on information technology industry. 2nd International Conference on Advances in Computer Science and Engineering, Vol, 330-333.

Cole, C., Yan, Y., \& Hemley, D. (2015). Does capital structure impact firm performance: An empirical study of three U.S. sectors? Journal of Accounting and Finance, Vol, 15(6), 57-65.

Crotty, J. (2009). Structural causes of the global financial crisis: a critical assessment of the "new financial architecture. Cambridge Journal of Economics, Vol, 33(4), 563-580.

Daskalakis, N., \& Psillaki, M. (2008). Do country or firm factors explain capital structure? Evidence from SMEs in France and Greece. Applied Financial Economics, Vol, 18, 87-97.

Daskalakis, N., \& Psillaki, M. (2008). Do countries or firm factors explain capital structure: Evidence from SMEs in France and Greece? Applied Financial Economics, Vol, 18, 87-97.

Demirhan, H., \& Anwar, W. (2014). Factors affecting the financial performance of the firms during the financial crisis: Evidence from Turkey. Edge Strategic Research Journal, Vol, 5(2), 65-80.

Ebaid, I. E. S. (2009). The impact of capital-structure choice on firm performance: empirical evidence from Egypt. The Journal of Risk Finance, Vol, 10(5), 477-487.

Eldomiaty, T. (2008). Determinants of corporate capital structure: evidence from an emerging economy. International Journal of Commerce and Management, Vol, 17, 25 - 43.

Elfakhani, S., Ghantous, R. F., \& Baalbaki, I. (2003). Mega-mergers in the US banking industry. Applied Financial 
Economics, Vol, 13, 609-622.

Erkens, Hung, \& Matos. (2012). corporate governance in the 2007-2008 financial crises: Evidence from financial institutions worldwide. Journal of Corporate Finance, Vol, 18, 389-411.

Figueira, C., \& Nellis, J. (2009). Bank merger and acquisitions activity in the EU: Much ado about nothing. The Service Industries Journal, Vol, 29, 875-886.

Fosberg, S. (2012). Capital structure and financial crisis. Journal of Finance and Accountancy, Vol, 11, 46-52.

Frank, M. Z., \& Goyal, V. K. (2009). Capital structure decisions: Which factors are reliably important? Financial Management, Vol, 38, 1 - 37.

Gangeni, C. (2006). The Relationship between capital structure and the financial performance of the firm. Retrieved from Master Thesis: University of Pretoria, South Africa.

Gansuwan, P., \& Önel, C.Y. (2012). The Influence of capital structure on firm performance: A quantitative study of Swedish listed firms. Umea Sweeden.

Grove, H., Patelli, L., Victoravich, M., \& Xu, P. (2011). Corporate governance and performance in the wake of the financial crisis: Evidence from US commercial banks. Corporate Governance: An International Review, Vol, 19, 418-436.

Hensel, N. D. (2006). Cost-efficiencies, profitability, and strategic behavior. International Journal of Managerial Finance, Vol, 2, 49 - 76.

He, T. (2013). The comparison of impact from capital structure to corporate performance between Chinese and European listed firms. Retrieved from Master Thesis, Jonkoping University, Swedish.

Hossain, A. T., \& Nguyen, D. X. (2016). Capital Structure, firm performance and the recent financial crisis. Journal of Accounting and Finance, Vol, 16(1), 76-89.

Jain, M. K. (2015). Factors effecting capital structure of pharma firm in India: A case study of firm's listed on CNX index of NSE. International Journal of Multidisciplinary Approach, Vol, 2, 54-65.

Jensen, M. C., \& Meckling, W. H. (1976). Theory of the firm: Managerial behavior, agency costs and ownership structure. Journal of Financial Economics, Vol, 3(4), 305-360.

Karadeniz, E., Kandir, S. Y., Balcilar, M., \& Onal, Y. B. (2009). Determinants of capital structure: Evidence from Turkish lodging companies. International Journal of Contemporary Hospitality Management, Vol, 21(5), $594-609$.

Kausar, A., Mian, S. N., \& Hashim, A. B. (2014). Capital structure and firm value: Empirical evidence from Pakistan. Asian Journal of Research in Economics and Finance, Vol, 1, 11-22.

Khan, W., Naz, A., Khan, M., \& Ahmad, S. (2013). The impact of capital structure and financial performance on stock returns: A case of Pakistan textile industry. Middle-East Journal of Scientific Research, Vol, 16 (2), 289-295

Khodavandloo, M., Zakaria, Z., \& Nassir, A. M. (2017). Capital structure and firm performance during global financial crisis. International Journal of Economics and Financial Issues, Vol, 7(4), 498-506.

Kouser, R., \& Saba, I. (2011). Effects of business combination on financial performance: evidence from Pakistan's banking sector. Australian Journal of Business and Management Research, Vol, 1, 54-64.

Kumar, S., \& Bansal, L. K. (2008). The impact of mergers and acquisitions on corporate. Management Decision, Vol, 46, 1531-1543.

Kumar, S., \& Gulati, R. (2009). Measuring efficiency. International Journal of Productivity and Performance Management, Vol, 59, 51-74.

Malm, S., \& Roslund, E. (2013). The bond-to-total debt ratio and its impact on firms' performance. Retrieved from http://www.diva-portal.org/smash/get/diva2:635624/FULLTEXT01.pdf

McKibbin, W. J., \& Stoeckel, A. (2009). The global financial crisis: Causes and consequences. In $\operatorname{te}$ e $n$ a $t$ i o $n$ a l Econ o my Program, Vol, 2(9), 1-39.

Miller, M. (1977). Risk, uncertainty, and divergence of opinion. The Journal of Finance, Vol, 32(4), 1151-1168.

Modigliani, F., \& Miller, M. (1958). The cost of capital, corporation finance and the theory of investment. American Economic Review, Vol, 48, 261-275.

Modigliani, F., \& Miller, M. (1963). Corporate income taxes and the cost of capital. American Economic Review, Vol, 53, 433-443.

Moosa, I., \& Li. (2012). Firm-Specific factors as determinants of capital structure: evidence from Indonesia. Review of Pacific Basin Financial Markets and Policies, Vol, 15, 1-17.

Mostafa, M. (2007). Modeling the efficiency of GCC bank: A data envelopment analysis approach. International Journal of Productivity and Performance Management, Vol, 56, 623-643.

Mostafa, M. (2007). Benchmarking top Arab banks 'efficiency through efficient frontier analysis. Industrial Management and Data Systems, Vol, 107, 802-823.

Mouamer, F. (2011). The determinants of capital structure of Palestine-listed companies. The Journal of Risk Finance, Vol, 12, 226-241.

Myers. S. C. (1984). The capital structure puzzle. The Journal of Finance, Vol, 39, 575-592. 
Myers, S. C., \& Majluf, N. S. (1984). Corporate financing and investment decisions when firms have information those investors do not have. Journal of Financial Economics, Vol, 13, 187-221.

Mujahid, M., \& Akhtar, K. (2014). Impact of capital structure on firms financial performance and shareholders wealth: Textile sector of Pakistan. International Journal of Learning and Development, Vol, 4(2), 27-33.

Muzir, E. (2011). Triangle relationship among firm size, capital structure choice and financial performance. Journal of Management Research, Vol, 11(2), 87- 98.

Niu, K. (2008). Theoretical and practical review of capital structure and its determinants. International Journal of Business and Management, Vol, 3, 133-139.

Olawale, L. S., Ilo, B. M., \& Lawal, F. K. (2017). The effect of firm size on performance of firms in Nigeria. The Ieb International Journal of Finance, Vol, 15, 2-21.

Omoye. S. A., \& Aniefor, S. (2016). The trend in business environment in Nigeria. Accounting and Finance Research, Vol, 5(2), 10-19.

Panetta, F. \& Salleo , C. (2002). Why do banks merge? Journal of Money, Credit and Banking, Vol, 34, $1047-$ 1066.

Pasiouras, F., \& Zopounidis, C. (2008). Consolidation in the Greek banking industry: Which banks are acquired? Managerial Finance, Vol, 34, 198-213.

Pontoh, W., \& Ilat, V. (2013). Determinant capital structure and profitability impact (study of listed company in Indonesian stock exchange). Research Journal of Finance and Accounting, Vol, 4, 43-49.

Popovici, A. N. (2014). The impact of mergers and acquisitions on the market value of shares of Erste bank group. Timisoara Journal of Economics and Business, 2286-0991, Vol, 7, 102-112.

Pouraghajan, E. A. (2012). The relationship between capital structure and firm performance evaluation measures: Evidence from the Tehran Stock Exchange. International Journal of Business and Commerce, Vol, 1(9), 166181.

Quiry, E. A. (2009). Corporate Finance Theory and Practice. $\left(2^{\text {nd }}\right.$ Ed.) United Kingdom: John Wiley \& Sons Ltd.

Rehman, R. U., \& Raoof, A. (2010). Efficiencies of Pakistani banking sector: A comparative study. International Research Journal of Finance and Economics, Vol, 46, 111-128.

Rouf, K. (2015). Capital structure and firm performance of listed non-financial companies in Bangladesh. The International Journal of Applied Economics and Finance, Vol, 9(1), 25-32.

Salamat, P., \& Mustafa, K. (2016). The impact of capital structure on stock return: Empirical evidence from Amman Stock Exchange. International Journal of Business and Social Science, Vol, 7, 183-196.

Salim, M., \& Yadav, D. (2012). Capital structure and firm performance: Evidence from Malaysian listed companies. Procedia - Social and Behavioral Sciences, Vol, 65, 156 - 166.

San, S., \& Heng, K. (2011). Capital structure and corporate performance of Malaysian construction sector. International Journal of Humanities and Social Science, Vol, 1(2), 28-36.

Sheikh, N. A., \& Wang, Z. (2011). Determinants of capital structure an empirical study of firms in manufacturing industry of Pakistan. Managerial Finance, Vol, 37(2), 117 - 133.

Sufian, F. (2007). Trends in the efficiency of Singapore are commercial. International Journal of Productivity and Performance Management, Vol, 56, 99-136.

Tahmoorespour, R., Ali-Abbar, M., \& Randjbaran, E. (2015, March). The impact of capital structure on stock returns: International evidence. Hyperion Economic Journal, Vol, 1(3), 56-78.

Taiwo, A., Muyideen, O., \& Tunde, S. (2015). Impact of capital structure on corporate performance: A pre and post crisis evaluation of selected companies in US. International Journal of Accounting Research (IJAR), Vol, 2, 1-20.

Tongkong, S. (2012). Key factors influencing capital structure decision and its speed of adjustment of Thai listed real estate companies. Social and Behavioral Sciences, Vol, 40, 716 - 720.

Umar, M., Tanveer, Z., Aslam, S., \& Sajid, M. (2012). Impact of capital structure on firms' financial performance: Evidence from Pakistan. Research Journal of Finance and Accounting, Vol, 3(9), 1-12.

Velnampy, T., \& Niresh, J. A. (2012). The relationship between capital structure and profitability. Global Journal of Management and Business Research, Vol, 12(13), 67-74.

Wood, F., \& Sangster, A. (2002). An assessment of compliance with IFRS framework at first-time adoption by the quoted banks in Nigeria business accounting. Journal of Finance and Accounting, Vol, 2(3), 64-73. 